\title{
INFLUENCE OF MOLDING WATER CONTENT ON SHEAR STRENGTH CHARACTERISTIC OF COMPACTED CEMENT KILN DUST TREATED LATERITIC SOILS FOR LINERS AND COVERS
}

\author{
K. J. Osinubi ${ }^{1}$, G. Moses ${ }^{2,}{ }^{*}$, F. O. P. Oriola ${ }^{3}$ and A. S. Liman ${ }^{4}$ \\ 1 DePARTMENT OF Civil ENGinEERING, AHMADU Bello University, ZARIA \\ 2,3 Department of Civil EngineERing, Nigeria DefEnCE ACADEMy, Kaduna \\ 4 Federal Capital Development Authority, ABuja, Nigeria. \\ E-mail addresses:1 kosinubi@yahoo.com,2doveeagle4al@yahoo.com,3 dansulayman@yahoo.com, \\ 4 oree21257@yahoo.com
}

\begin{abstract}
A laboratory investigation was carried out to determine the shear strength characteristics of compacted cement kiln dust treated lateritic soils for use in liners and covers with up to $12.5 \%$ cement kiln dust by dry weight of soil. Specimens were prepared at molding water contents of $-2,0,+2$ and $+4 \%$ of the optimum moisture content at the compactive energy levels of the British standard light (BSL), West African Standard (WAS) or "intermediate" and British standard heavy (BSH). Specimens treated with cement kiln dust met the minimum UCS value of $200 \mathrm{kN} / \mathrm{m}^{2}$ requirement. Generally, the recorded UCS values for lateritic soil - cement kiln dust mixtures produced satisfactory UCS values for all the compactive energy levels considered. However, due to the unavailability of water to meet the hydration demand of the cement kiln dust pozolana no significant improvement in UCS values was recorded beyond 2.5\% for cement kiln dust treated specimens compacted at BSH energy level and especially on the dry side of optimum moisture content.
\end{abstract}

Keywords: Cement kiln dust, Compaction, Molding water content, Unconfined compressive strength.

\section{INTRODUCTION}

Sanitary landfill is the most cost-effective system of solid wastes disposal for most urban areas in developing and industrialized countries. It is a step by step construction activity involving daily layering, compacting, soil covering of refuge in cells and routing of surface run - off away from wastes cell. The refuse is spread, compacted and covered periodically (daily at close of work) with soil of about $15-30 \mathrm{~cm}$ thick. Thus forming series of cells encapsulated with soil which ranges up to about $5 \mathrm{~m}$ thick.

In order to ensure the structural integrity of a constructed landfill facility compacted soils for the liner and cover systems adequate strength must ensured [1]. Adequate shear strength of liner or cover system must be such that it can support the overburden imposed by the water body and the self weight of the liners and cover itself. The shear strength of compacted clay depends on the density as well as water content, clays compacted dry of optimum are initially stronger than when compacted wet of optimum. Compacted soil strength can be evaluated in terms of confined compression strength, [1] selected minimum unconfined compressive strength of $200 \mathrm{kN} / \mathrm{m}^{2} \quad(200 \mathrm{kPa})$ to represent adequate shear strength for compacted soil liner and cover. A minimum unconfined compressive strength of $200 \mathrm{kN} / \mathrm{m}^{2}$ is considered sufficient durable in satisfying the stresses resulting from alternate wet/dry and freeze/ thaw cycles [1,2].This strength is the lowest value for very stiff soils based on the consistency classification according to [3].

Large quantities of waste materials from mineral, agricultural, domestic and industrial sources are generated daily and the safe disposal of these wastes are increasingly becoming a major concern around the world [4]. These wastes, if properly treated, could be modified for use as structural components of highway 
pavements or as waste containment materials. Therefore, recent studies have been geared towards the utilization of waste resources to stabilized soils to improve the engineering and allied properties of pavement base course material liners [5]. The use of these waste resources evolved out of need to economically utilize industrial by - products in an attempt to solve environmental problems associated with the increasing amount of wastes in many parts of the world. However, [6] reported that most industrial wastes have little or no cementation values but react with lime or OPC in the presence of moisture to form compounds possessing cementitious properties.

Cement manufacturing is a critically important industry in the whole world. As with most large manufacturing industries, by-products are generated. Cement kiln dust is a fine grained solid material generated as the primary inherent process residue at all cement plants. In 1990, it was reported that an average 9 tons of Cement kiln dust was produced for every 100 tons of clinker in the U.S.A. [7]

As an industrial by product, the composition of cement kiln dust is a function of many variables. Cement kiln dust is comprised of thermally unchanged raw materials, dehydrated clay, decarbonated (calcined) limestone, ash from fuel and newly formed Minerals corresponding to all stages of the clinker [8]. An unusual feature of CKD is that, unlike typical process wastes, that are substantially different from the product, Cement kiln dust is essentially cement that does not quite meet commercial specifications. Although, the relative constituent concentrations in CKD can vary significantly, CKD has certain physical characteristics that are relatively consistent. When stored fresh, CKD is a fine, dry alkaline dust that readily absorbs water, when managed on site in a waste pile, CKD can retain these characteristics within the pile while developing an externally weathered crust, due to absorption of moisture and subsequent cementation of dust particles on the surface of the pile. The ability of CKD to absorb water stems from its chemically dehydrated nature, which results from the thermal treatment it receives in the kiln system.

(UCS) value can be estimated using the following equations:

$U C S=\left((R C r)\left(1-\left(L_{1} / L o\right)\right)\right) / 100 A o$

In (1), $A_{0}$ is the initial area of cross-section $\left(\mathrm{mm}^{2}\right), \varepsilon \%$ $=\mathrm{x} / \mathrm{L}_{0}, \varepsilon \%=$ axial strain percent, Lo is the initial length of specimen, $\mathrm{D}$ is the initial diameter of specimen $(\mathrm{mm}), \mathrm{C}_{\mathrm{r}} \mathrm{N} /$ division $=$ mean calibration of load ring, $\mathrm{R}$ divisions $=$ load ring reading at strain, $\varepsilon ; \mathrm{A}$ $\left(\mathrm{mm}^{2}\right)$ is the area of cross-section at strain,; $\mathrm{R} \times \mathrm{C}_{\mathrm{r}}$ (Newtons) is the load on specimen at strain, $\varepsilon$ and $\sigma$ is the compressive stress at strain, $\varepsilon$. The ring calibration $\mathrm{C}_{\mathrm{R}}$ can be assumed to be constant.

\section{MATERIALS AND METHODS}

\subsection{Soil}

The reddish brown lateritic soil used in this study was obtained from a burrow pit by method of disturbed sampling at $\mathrm{Km} 15$ along the Zaria-Sokoto road in Zaria (latitude $11^{015}$ and longitude $7045^{\prime}$ E), Kaduna State Nigeria. The soil is classified as CL according to the unified soil classification system. X-ray diffraction (XRD) and differential thermal analysis (DTA) of soil from the study borrow area reported by $[9,10]$ show that the clay mineralogy is predominantly kaolinite. The physical properties of the soil are summarized in Table 1.

\subsection{Cement Kiln Dust}

The cement kiln dust used was obtained from freshly deposited heaps of the waste at the Ashaka cement production plant located in Nafada Local Government Area of Gombe state, (Latitude $0^{\circ} 19^{\prime} \mathrm{N}$ and Longitude $\left.11^{\circ} 30^{\prime} \mathrm{E}\right)$, Nigeria. The CKD is brownish in color with a specific gravity of 1.90. The CKD was sieved through BS sieve No. 200 and was stored in airtight containers before usage. Specimens of cement kiln dust were sieved through British Standard sieve of 75 microns after grinding. The portion passing the sieve was compared to the required degree of fineness, that is 63 microns and below while the cement kiln dust retained on the sieve was reground and sieved again. Chemical analysis of CKD was carried out at Chemical Laboratory of the Energy Research Centre, Ahmadu Bello University Zaria. The X-ray Analyzer together with Atomic Absorption Spectrophotometer (AAS) was employed for the analysis except for Sulphur Oxide, Sodium and Potassium Oxide where the Flame Analyzer was used, gravimetric method was employed in the determination of the Carbonate and Hydrogen Carbonate. The chemical composition of the cement kiln dust is shown in Table2.

\subsection{Index Properties}

Index properties tests on the natural soils were carried out in accordance with [11-13]. The index property of the untreated lateritic soil is shown in Table 3. 


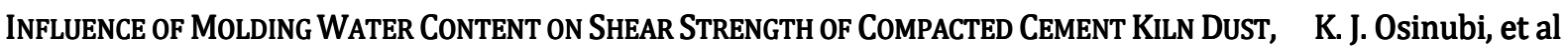

Table 1: Oxide Composition of the Lateritic Soil

\begin{tabular}{cc}
\hline Oxide & Concentration (\%) \\
\hline $\mathrm{CaO}$ & 0.28 \\
$\mathrm{Al}_{2} \mathrm{O}_{3}$ & 27.4 \\
$\mathrm{SiO}_{2}$ & 35.6 \\
$\mathrm{Fe}_{2} \mathrm{O}_{3}$ & 24.0 \\
$\mathrm{Mn}_{2} \mathrm{O}_{3}$ & 2.0 \\
$\mathrm{Na}_{2} \mathrm{O}$ & - \\
$\mathrm{K}_{2} \mathrm{O}$ & 1.4 \\
$\mathrm{~S}_{2} \mathrm{O}$ & 0.85 \\
$\mathrm{LOI}$ & 1.46 \\
\hline
\end{tabular}

Table 2: Oxide Composition of the Cement kiln dust

\begin{tabular}{cc}
\hline Oxide & Concentration \\
\hline $\mathrm{CaO}$ & 50.8 \\
$\mathrm{Al}_{2} \mathrm{O}_{3}$ & 4.71 \\
$\mathrm{SiO}_{2}$ & - \\
$\mathrm{Fe}_{2} \mathrm{O}_{3}$ & 1.92 \\
$\mathrm{Mn}_{2} \mathrm{O}_{3}$ & 0.002 \\
$\mathrm{Na}_{2} \mathrm{O}$ & 0.001 \\
$\mathrm{~K}_{2} \mathrm{O}$ & 1.35 \\
$\mathrm{pH}$ & 11.20 \\
$\mathrm{Gs}$ & 1.90 \\
\hline
\end{tabular}

Table 3: Physical Properties of Untreated Lateritic Soil

\begin{tabular}{ll}
\hline Engineering Properties & Quantity \\
\hline Liquid Limit, \% & 42.6 \\
Plastic Limit, \% & 26.1 \\
Plasticity Index, \% & 16.5 \\
Linear Shrinkage, \% & 12.1 \\
Percentage Passing BS No. 200 Sieve. & 54.6 \\
Group Index & 6 \\
AASHTO Classification & A-7-6 \\
USCS Classification & CL \\
Specific Gravity & 2.71 \\
MDD Mg/m ${ }^{3}$ & 1.71 \\
British Standard Light & 1.79 \\
West African Standard & 1.88 \\
British Standard Heavy & 17.5 \\
OMC\% & 15.0 \\
British Standard Light & 12.5 \\
West African Standard & 6.7 \\
British Standard Heavy & \\
pH Value & Reddish \\
Colour & Brown \\
Dominant Clay mineral & Kaolinite \\
\hline
\end{tabular}

\subsection{Compaction}

All the compactions involving moisture-density relationships and UCS were carried out using energies derived from the British standard light (BSL), West African Standard (WAS) and British standard light (BSH) energies in accordance with $[12,13]$. The BSL compactions was carried out using energy derived from a rammer of $2.5 \mathrm{~kg}$ mass falling through a height of $30 \mathrm{~cm}$ in a $1000 \mathrm{~cm}^{3}$ mould. The soil was compacted in three layers, each receiving 27 blows.

The WAS compaction, was carried out using energy derived from a rammer of $4.5 \mathrm{~kg}$ mass falling through a height of $45 \mathrm{~cm}$ in a $1000 \mathrm{~cm}^{3}$ mould. The soil was compacted in five layers, each layer receiving 10 blows.

\subsection{Unconfined Compression}

Dried lateritic - cement kiln dust mixtures were compacted at optimum moisture content using the three 3-compactive efforts of BSL, WAS and BSH. Tests specimen were compacted at $-2 \% \mathrm{OMC}$, OMC, $+2 \% \mathrm{OMC}$ and $+4 \% \mathrm{OMC}$ respectively using the three 3-compactive efforts stated earlier. The cylindrical specimens used in this test are of diameter $38.1 \mathrm{~mm}$ and height $76.2 \mathrm{~mm}$ at the specified height to diameter ratio of 2.1 in accordance with [12, 13]. After compaction, the treated lateritic soil was extruded from the mold and sealed with double wrappings in polythene bags that were kept in the humidity room at a constant temperature of $25 \pm 2^{\circ} \mathrm{C}$. This was done for a period 72 hours to allow for uniform moisture distribution and curing. After curing, specimens were placed in a load frame machine driven strain controlled at $0.10 \% / \mathrm{min}$ and crushed until failure occurred.

\section{DISCUSSION OF RESULTS}

\subsection{Maximum dry density}

There was a general decrease in maximum dry density at the energy level of BSL shown in Figure 1. Generally the all compactive energy level recorded a decrease in MDD with higher CKD content, this finding is in agreement with similar report by [14]. Furthermore, this trend can be attributed to the presence of a large amount of low density aggregate particles and it could possibly be attributed to cement kiln dust, a low specific gravity material (1.90) replacing the lateritic soil which has a high specific gravity of 2.71 [15].

\subsection{Optimum moisture content}

Generally there is an increase in the optimum moisture content as shown in Figure 2. This increase could be attributed to the increasing demand for more moisture by the various cations to undergo hydration reaction [15]. Furthermore, the increase in fines content resulting from the inclusion of cement kiln dust with larger surface area will lead to more demand for water to react with.

\subsection{Unconfined compressive strength 3.3.1 Effect of molding water content}

The minimum required strength of soil to be used in compacted soil liners is not specified however, [1] 


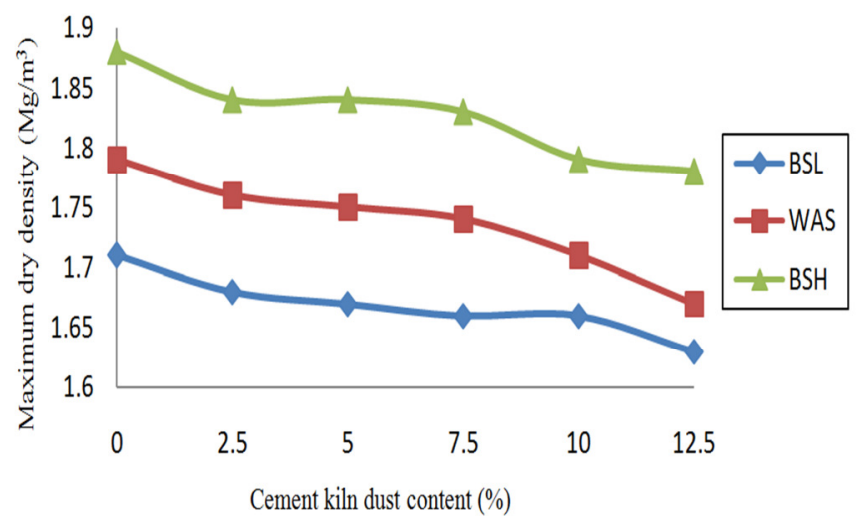

Figure 1: Variation of maximum dry density of cement kiln dust treated lateritic soil

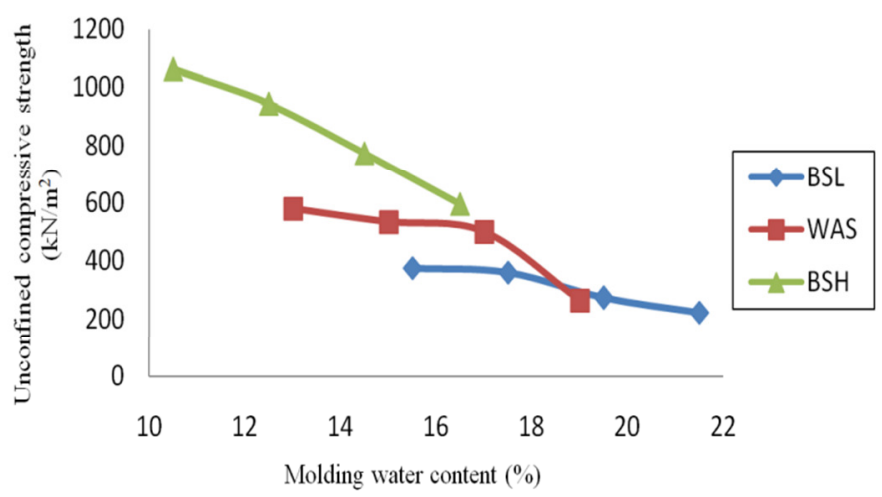

Figure 3: Variation of unconfined compressive strength with moulding water content for natural lateritic soil

arbitrarily selected a minimum of $200 \mathrm{kN} / \mathrm{m}^{2}$ to support the maximum bearing stress in a landfill. The variations of unconfined compression strength (UCS) with molding water content are shown in Figures 3, 4, 56 , and 8.

Generally, the UCS of the mixtures decreased with increase in molding water content, this is in agreement with the findings of other researchers [1, 16, 17 and 18]. The untreated lateritic soil exhibited the same pattern in behavior as recorded by previous researchers. But the treated specimens' exibited slight variations in behavior due to the inclusion of pozzolanic cement kiln dust in lateritic soil. The UCS values beyond $0 \%$ CKD treatment of lateritic soil especially at BSH compactive effort exhibited trend that indicated that better UCS values are not obtained at the dry side of optimum. Rather, after 0\% CKD treatment, a reduction in UCS value was recorded on the dry side of optimum, this is in agreement with the findings reported by [19].

The minimum UCS value recommended by [1] was satisfied by the lateritic soil specimens (see Figure 3) prepared at molding water content in the range 15.5 $21.5 \%, 13.0-19.0 \%$ and $10.5-16.5 \%$ for BSL, WAS and BSH compactive energy levels, respectively. This trend of variation in UCS values with water content

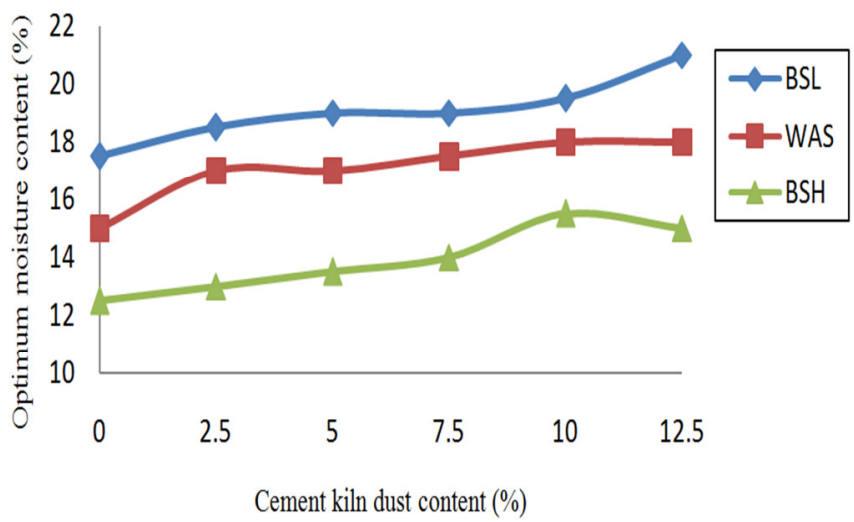

Figure 2: Variation of optimum moisture content of cement kiln dust treated lateritic soil

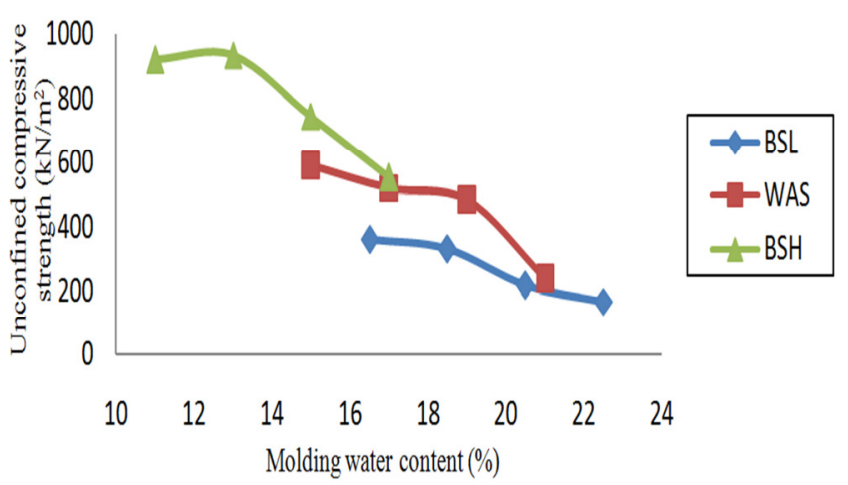

Figure 4: Variation of unconfined compressive strength with moulding water content at $2.5 \%$ cement kiln dust treatment

values for the lateritic soil is consistent with other research work $[1,17,18,20$ and 21].

At $2.5 \%$ CKD treatment (see Figure 4), specimens satisfy the minimum UCS requirement of $200 \mathrm{kN} / \mathrm{m}^{2}$ according to [1]. Specimens compacted with BSL, WAS and BSH energies produced satisfactory UCS values at molding water contents in the ranges $16.5-20.8,13.0$ - 19.0 and 16.5 - 20.8\%, respectively. Samples treated with 5.0\%, CKD content (see Figure 5), recorded minimum UCS values that were obtained at molding water contents in the range of $17.0-22.0$, $15.0-21.0$ and $11.5-17.5 \%$ for BSL, WAS and BSH compactions, respectively. At $7.5 \%$ CKD treatment (see Figure 6), minimum UCS values were obtained at molding water content ranges of $17.0-22.0,15.5$ 21.5 and $12.0-18.0 \%$ at BSL, WAS and BSH compactive efforts respectively. At 10.5\% CKD treatment (see Figure 7), minimum UCS values were obtained at molding water content ranges of 17.5 22.6, $16.0-22.0$ and $13.5-19.54 \%$ at BSL, WAS and BSH compactive efforts respectively. Finally, at $12.0 \%$ CKD treatment (see Figure 8) satisfactory UCS values were obtained at molding water contents in the ranges $19.0-21.0,16.0-22.0$ and $13.0-19.0 \%$ for BSL, WAS and BSH compactive efforts respectively. 


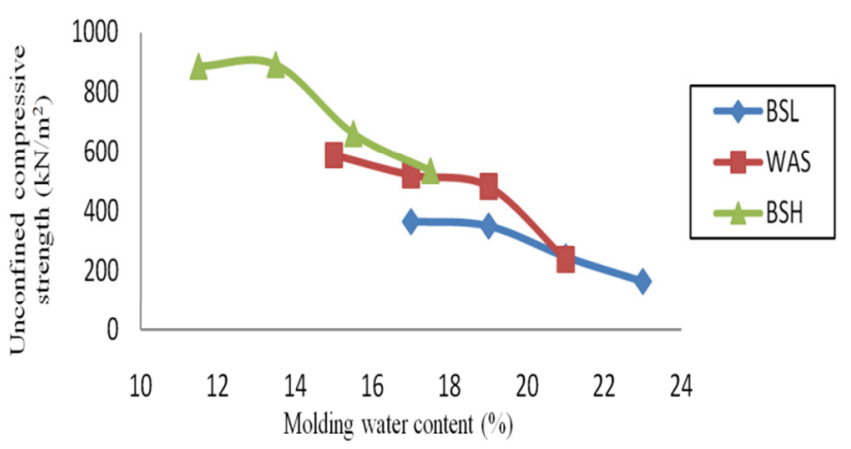

Figure 5: Variation of unconfined compressive strength with moulding water content at 5.0\% cement kiln dust treatment

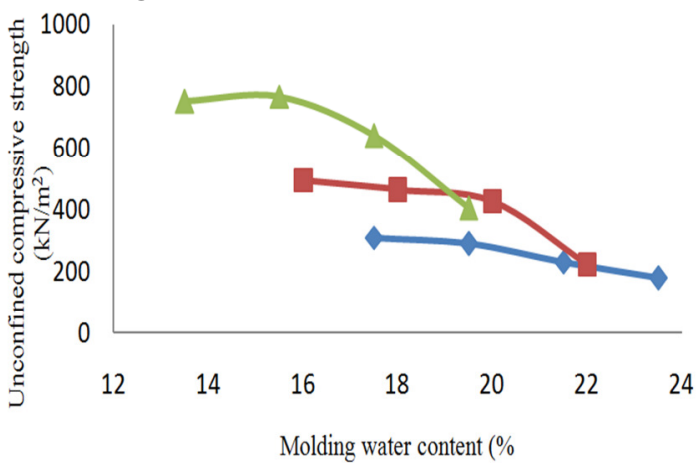

Figure 7: Variation of unconfined compressive strength with moulding water content at $10.0 \%$ cement kiln dust treatment

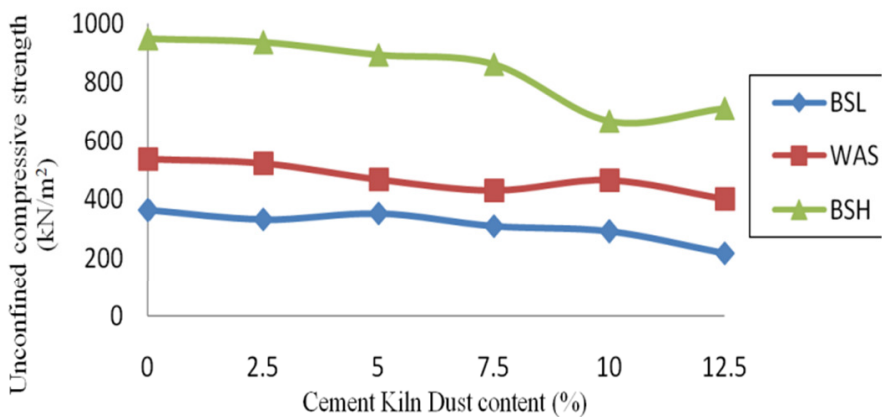

Figure 9: Variation of unconfined compressive strength with cement kiln dust treatment

CKD treatment of lateritic soils recorded results that showed marked deviation from the regular pattern of UCS values. On the dry side of optimum, lower values were recorded, especially for compactions at the BSH energy level. This trend could be as a result of the molding water contents being insufficient to meet the hydration demand of the cement kiln dust pozzolana [22]. Generally, UCS values increased with higher compactive effort. This trend is attributed to closer packing of the soil fabric at high energy level $[18,23]$.

\subsubsection{Effect of Cement Kiln Dust Content}

The variation of UCS with cement kiln dust content for compactions at the energy levels of BSL, WAS and BSH of specimens were prepared at optimum moisture content as shown in Figure 9. Generally, UCS values of

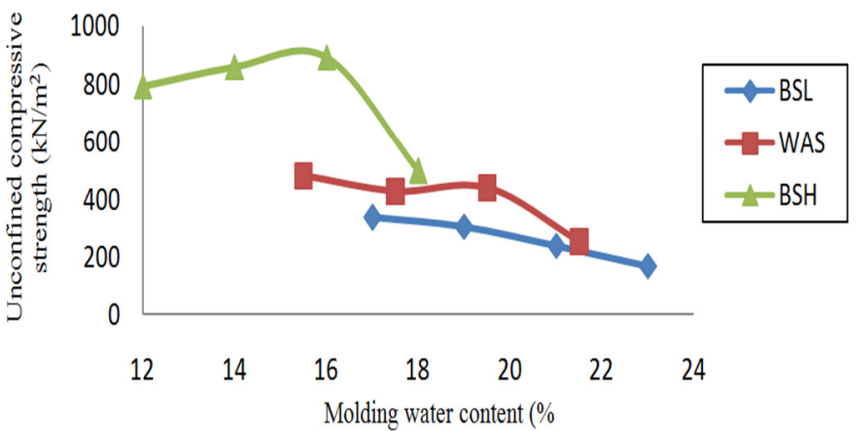

Figure 6: Variation of unconfined compressive strength with moulding water content at $7.5 \%$ cement kiln dust treatment

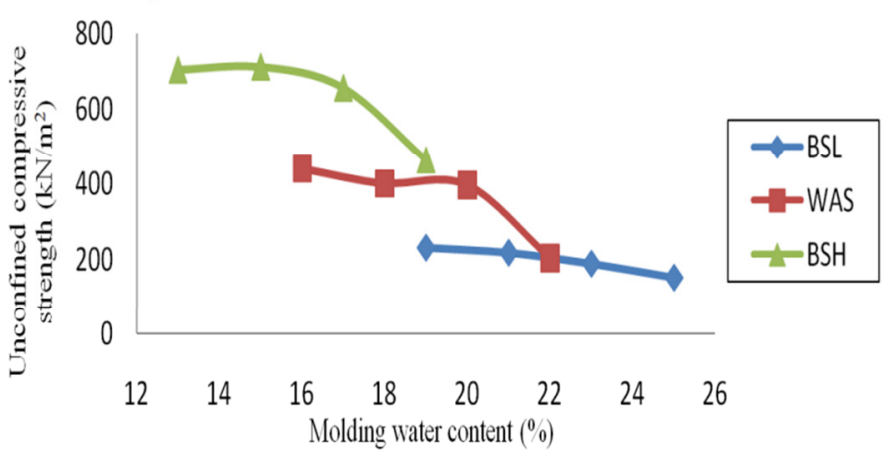

Figure 8: Variation of unconfined compressive strength with moulding water content at $12.5 \%$ cement kiln dust treatment

treated specimens decreased slightly this can be attributed to cation exchange reaction which results in the formation bonds that are weak due to incomplete hydration reaction. This result is consistent with other similar research works [19, 24 and 25].

\section{CONCLUSION}

Laboratory tests were carried out on lateritic soil treated with up to $12.5 \%$ cement kiln dust (a pozzolana as well as an industrial waste) to assess its shear strength suitability for use in liners and covers for waste containment facilities. Specimens prepared at moulding water contents $-2,0,+2$ and $-4 \%$ of the optimum moisture content were compacted at three energy levels (British Standard light, West African Standard, and British Standard heavy). The plastic lateritic soil was classified as A-7-6(6) and CL according to AASHTO and USCS. Generally, MDD decreased and OMC increased, respectively, with higher cement kiln dust content.

Generally, the recorded UCS values for lateritic soil cement kiln dust mixtures produced satisfactory UCS values up to $12.5 \%$ cement kiln dust treatment for all the compaction energy levels considered. However, no significant improvement in UCS values was recorded beyond $2.5 \%$ cement kiln dust treated specimens compacted at BSH enegy level and especially on the dry side of optimum moisture content. Other 
compactive efforts recorded increase in UCS values up to $12.5 \%$ cement kiln dust treatment due to the availability of water that meet the hydration demand of the pozolana.

\section{REFERENCES}

[1] Daniel D.E. and Wu, .Y. K. (1993), 'Compacted clay liners and covers for arid sites', Journal of Geotechnical Engineering. A.S.C.E., 119(2): 223-237.

[2] Edil, T.B. Linda, K. S. and Berthouex, P.M. (1992), 'Interaction of inorganic leachate with compacted pozzolanic fly ash', Journal of Geotechnical Engineering, 118(9): 1410 - 1430.

[3] Peck, R.B., Hanson, W.E., and Thornburn, T.H. (1974) Foundation Engineering. John Wiley and Sons, Inc.: New York, NY. 514

[4] ETL 1110-3-503 (1999) Use of waste materials in pavement construction, EngineeringTechnical Letter, $B-1$ to $B-22$.

[5] Cavey, J. K., Krizek, R.J., K. and Baker, W. H. (1995), 'Waste fiber in Cement Stabilized recycled aggregate base coarse material', Transportation Research Record, No. 1466, National Academy Press Washington DC, 97 - 106.

[6] O’Flaherty, C. A. (1974 Highway Engineering Vol. 2, Edward Arnold, London, U.K

[7] Kessler, G.R., (1995) Cement Kiln Dust (CKD) methods for reduction and control. IEEE Transaction On Industry Application, 31(2)

[8] Kohlhaas, B., et al., 1983. Cement Engineer's Handbook. Bauverlag GMBH, Wiesbaden and Berlin. p. 624.

[9] Osinubi, K.J. (1998a). Influence of compactive efforts and compaction delays on lime treated soils. Journal Transportation Engineering. A.S.C.E., 124(2): 149-155.

[10] Osinubi, K.J. (1998b), 'Pemeability of Lime treated laterite soil', Journal of Transportation Engineering, A.S.C.E., 124(5): 456-469.

[11] AASHTO (1986), Standard Specification for Transportation Materials and Methods of Sampling and Testing, $14^{\text {th }}$ Edition. Am. Assoc. of State Hwy. and Transp. Officials, Washington, D.C.

[12] BS 1377 (1990) Methods of Testing Soils for Civil Engineering Purposes. British Standard Institute, London.

[13] BS 1924 (1990). Methods of Tests for Stabilized Soils. British Standard Institute, London.

[14] Yoder, E. J. and Witczak, M. W. (1975) Principles of Pavement Design. John Wiley and Sons. Inc. New York, $300-321$.

[15] Osinubi, K.J. and Stephen, T.A. (2005), 'Economic utilization of an agro-industrial waste Bagasse ash', Proceedings $4^{\text {th }}$ Nigerian Materials Congress, NIMACON2005, November, Zaria, pp. 36.
[16] Seed, H.B., and Chan, C.K. (1959), 'Structure and Strength Characteristic of Compacted Clays', Journal of Soil Mechanics and Foundation Engineering A.S.C.E., 85(5): $87-128$.

[17] Taha, M.R., and M.H. Kabir (2003), 'Sedimentary Residual Soil as a Hydraulic Barrier in Waste Containment Systems', In: Proceedings of the International Conference on Recent Advances in Soft Soil Engineering and Technology, 2-4 July 2003. Putrajaya, Malaysia

[18] Taha, M.R., and Kabir, M.H (2005), 'Assessment of Physical Properties of a Granite Residual Soil as an Isolation Barrier', Electronic Journal of Geotechnical Engineering. EJGE, 60: 263-274.

[19] Osinubi, K. J., Bafyau, V. and Eberemu, A. O. (2007), 'Bagasse ash stabilization of lateritic soil. Proceedings', of the First International Conference on Environmental Resources, Technology and Policy "ERTEP 2007" under the auspices of International Society of Environmental Geotechnology, Accra, Ghana, 16 -19 July, Category E: State-of-the-Art Technologies for Environmental Performance and Protection, pp.1 - 17.

[20] Osinubi, K.J. and Nwaiwu, C.M.O. (2006a), 'Design of Compacted Laterite soils liners and cover', Journal of Geotechnical and Geoenvironmental Engineering. A.S.C.E., 132(2): 203 - 213.

[21] Osinubi, K.J., Eeremu, A.O. (2009a), 'Compatibility and Attenuative Properties of Laterite-blast Furnace Slag Mixtures', Journal of Waste Technology and Management 35(1): 7-16

[22] Stephen, I. T. (2010) Evaluation of compacted bagasse ash treated black cotton soil as hydraulic barriers in Waste containment systems. Unpublished Ph.D Dissertation submitted to the Department of Civil Engineering Ahmadu Bello University, Zaria.

[23] Eberemu, O. A. (2008) Evaluation of compacted bagasse ash treated lateritic soil as hydraulic barriers in waste containment systems. Unpublished Ph.D Dissertation submitted to the Department of Civil Engineering, Ahmadu Bello University, Zaria.

[24] Moses, G. (2012) Hydraulic and contaminant transport performance of compacted bagasse ash treated foundry sand for use in waste containment facilities. Unpublished Ph.D Dissertation submitted to the Department of Civil Engineering, Ahmadu Bello University, Zaria.

[25] Osinubi, K.J., Eeremu, A.O. (2009b), 'Desiccationinduced Shrinkage of Compacted Lateritic Soil Treated with bagasse ash', The Twenty-Fourth International Conference on Solid Waste Technology And Management CD-ROM, 15-18 March, Philidelphia, PA, U.S.A. Session 5C: Bioreactors and Innovative Landfills, pp.856-867. 